\title{
Effect of Integrated Nutrient Management on Seed Production of Olitorius Jute Raised from Top Cutting Method
}

\author{
Probodh Mandal ${ }^{1}$, S. S. Mondal ${ }^{2}$ and B. C. Patra ${ }^{2 *}$ \\ ${ }^{1}$ Dept. of Agronomy, College of agriculture (OUAT), Bhawanipatna,Kalahandi, Orissa (766 001), India \\ ${ }^{2}$ Dept. of Agronomy, BCKV, Mohanpur, Nadia West Bengal (741 252), India
}

\section{Article History}

Manuscript No. AR862

Received in $26^{\text {th }}$ July, 2014

Received in revised form $12^{\text {th }}$ June, 2015

Accepted in final form $15^{\text {th }}$ July, 2015

\section{Correspondence to}

*E-mail: probodh_mandalag@rediffmail.com

\section{Keywords}

Jute, top cutting, INM, growth, yield, nutrient

\begin{abstract}
A field experiment was conducted for two years during August-December of 2006 and 2007 to evaluate the effect of integrated nutrient management on seed production of olitorius jute (cv JRO-524) raised from top cutting with the application of $\mathrm{N}: \mathrm{P}_{2} \mathrm{O}_{5}: \mathrm{K}_{2} \mathrm{O}$ (a) 15:10:10 $\mathrm{kg} \mathrm{ha}^{-1}(\mathrm{RD})$ through inorganic sources and 75\% recommended dose (RD) of $\mathrm{N}, \mathrm{P}_{2} \mathrm{O}_{5} \& \mathrm{~K}_{2} \mathrm{O}$ through inorganic fertilizer along with $25 \% \mathrm{~N}$ through different sources of organic matter. The experiment was laid out in a Randomized Block Design with 9 treatment combinations replicated thrice. The treatments were $100 \% \mathrm{RDF}, 75 \%$ $\mathrm{RDF}+25 \% \mathrm{~N}-$ Karanja cake, $75 \% \mathrm{RDF}+25 \% \mathrm{~N}-\mathrm{Neem}$ seed powder, $75 \% \mathrm{RDF}+25 \%$ $\mathrm{N}-\mathrm{OM}$ rich with humas, $75 \% \mathrm{RDF}+25 \% \mathrm{~N}-$ Pelleted form of organic manure, $75 \%$ $\mathrm{RDF}+25 \% \mathrm{~N}$-vermicompost, 75\% RDF $+25 \% \mathrm{~N}$-Jatropha cake, 75\% RDF $+25 \%$

$\mathrm{N}-\mathrm{FYM}$ and $75 \% \mathrm{RDF}+$ Azospirillum. Among the integrated management treatments, $75 \% \mathrm{RDF}+25 \% \mathrm{~N}-\mathrm{FYM}$ proved best not only in influencing highest growth and yield but also in balancing soil nutrients.
\end{abstract}

\section{Introduction}

Seed plays an important role in agricultural sector since it is the key factor for improving the productivity, equality, diversification, value addition and sustainability component of our agriculture. Good quality seed of improved variety give the highest return relative to its cost. So it is not unusual that the farmers always give importance to seed. Jute is being cultivated in 0.835 mhaarea in India, spread over seven states like West Bengal, Bihar, Assam, Odisha, Meghalaya, Tripura and Uttar Pradesh and West Bengal is the leading state $(0.58$ $\mathrm{mha}$ ). The conservative estimate for the requirement of certified jute seed is around 5000 tones to grow jute crop in around 0.8 mha of land. Major seed growing areas are Andhra Pradesh, Maharashtra and Karnataka and major seed marketing areas are West Bengal, Bihar, Odisha and Assam. Now it is established that jute seeds can be produced in the edapho-climatic condition of West Bengal $(1,2)$. But the farmer of this intensive cropping region are not willing to spare their land for normal mode of jute seed production as it will occupy the land for more than 6 months. However the farmer of West Bengal may be interested in jute seed production, if the duration of land occupation is shortened considerably. With the said intention, to produce jute seeds in the southern plains of West Bengal by occupying the land only for 4-4.5 months, the present investigation was under taken to study the effect of integrated nutrient management on seed production raised from top cutting collected at harvest from the regular fibre crop. Earlier seed crop of jute was raised successfully by top cutting method under West Bengal condition.

\section{Materials and Methods}

A field experiment was conducted for 2 years during August-December of 2006 and 2007 at the Instructional Farm, $\left(22.95^{\circ} \mathrm{N}, 88.54^{\circ} \mathrm{E}\right)$ Jaguli, Bidhan Chandra KrishiViswavidyalaya, Mohanpur, Nadia, West Bengal to study the effect of olitorius jute (cv. JRO-524) raised from top cutting. Top cutting of $20 \mathrm{~cm}$ length collected from the 110 days fibre crop of jute were planted in moist soil during the first week of August. About 70-80\% survival of the cuttings were recorded. During the later part of the dry spell, two irrigations were given. The seed crop was harvested at 124 days age when the average plant height was $110-130 \mathrm{~cm}$. The experimental soil was sandy loam having PH 7.1, organic carbon- $0.42 \%$, total N-0.39\%, available P-26 kg ha-1 and available K-163 $\mathrm{kg} \mathrm{ha}^{-1}$. The experiment was laid out in a Randomized Block 
Design with 9 treatment combinations replicated thrice. The treatments were 100\% RDF, 75\% RDF+25\% N-Karanja cake, $75 \% \mathrm{RDF}+25 \% \mathrm{~N}-\mathrm{Neem}$ seed powder, $75 \% \mathrm{RDF}+25 \% \mathrm{~N}-\mathrm{OM}$ rich with humas, $75 \% \mathrm{RDF}+25 \% \mathrm{~N}$-Pelleted form of organic manure, $75 \%$ RDF $+25 \%$ N-vermicompost, $75 \% \mathrm{RDF}+25 \%$ N-Jatropha cake, 75\% RDF+25\% N-FYM and 75\% RDF+ Azospirillum. N,P and K were applied in the form of urea, SSP and MOP respectively. The recommended dose of fertilizer was $\mathrm{N}: \mathrm{P}_{2} \mathrm{O}_{5}: \mathrm{K}_{2} \mathrm{O} @ 15: 10: 10 \mathrm{~kg} \mathrm{ha}^{-1}$ respectively.

\section{Results and Discussion}

\subsection{Effect of INM on growth, yield attributes and yield}

Pooled data from the experiment revealed that $75 \% \mathrm{RDF}+25 \%$ N-FYM resulted highest maximum plant heights $(67.3 \mathrm{~cm}$, $85.7 \mathrm{~cm}$ and $117.5 \mathrm{~cm}$ ) of jute for seed production at $60 \mathrm{DAS}$, 80 DAS and at harvest respectively which was significantly higher than all treatments except 75\% RDF+25\% N-Neem seed powder $(66.4 \mathrm{~cm}, 84.9 \mathrm{~cm}$ and $114.5 \mathrm{~cm}$ respectively) (Table 1). The growth characters helped to record highest dry matter $\left(1504 \mathrm{~g} \mathrm{~m}^{-2}\right)$ that was significantly also higher than $100 \%$ RDF, 75\% RDF+25\% N-Karanja cake, 75\% RDF+25\% N-OM rich with humas, $75 \% \mathrm{RDF}+25 \% \mathrm{~N}$-Pelleted form of organic manure and $75 \% \mathrm{RDF}+25 \% \mathrm{~N}$-Jatropha cake treatments only. Highest number of branches plant ${ }^{-1}$, pods plant ${ }^{-1}$ and seeds pod ${ }^{-1}$ were also obviously maximum in the plot treated with $75 \%$ $\mathrm{RDF}+25 \% \mathrm{~N}-\mathrm{FYM}$. This treatment recorded highest number of branches plant ${ }^{-1}$ which was significantly higher than all treatments except $75 \% \mathrm{RDF}+25 \% \mathrm{~N}-\mathrm{Neem}$ seed powder. It was however statistically at par in recording number of pods ${ }^{-1}$ with the plot treated with $75 \% \mathrm{RDF}+25 \% \mathrm{~N}$-Neem seed powder and $75 \% \mathrm{RDF}+25 \% \mathrm{~N}$-vermicompost. Maximum number seeds pod $^{-1}$ was found in 75\% RDF $+25 \% \mathrm{~N}-\mathrm{FYM}$ which was significantly higher than $100 \% \mathrm{RDF}, 75 \% \mathrm{RDF}+25 \%$ $\mathrm{N}-$ Karanja cake, $75 \% \mathrm{RDF}+25 \% \mathrm{~N}-\mathrm{OM}$ rich with humas, $75 \% \mathrm{RDF}+25 \% \mathrm{~N}-$ Pelleted form of organic manure and $75 \%$ $\mathrm{RDF}+$ Azospirillum. Test weight, however was not influenced by different INM treatments. As per the trend, Highest seed yield $\left(0.52 \mathrm{t} \mathrm{ha}^{-1}\right)$ was achieved by $75 \% \mathrm{RDF}+25 \% \mathrm{~N}-\mathrm{FYM}$ that was statistically significant over 100\% RDF, 75\% RDF $+25 \%$ $\mathrm{N}-$ Karanja cake, $75 \% \mathrm{RDF}+25 \% \mathrm{~N}-\mathrm{OM}$ rich with humas, $75 \%$ $\mathrm{RDF}+25 \% \mathrm{~N}$-Jatropha cake and 75\% RDF+Azospirillum. Seed production of jute have been and area of major concern for years in west Bengal because farmers are more interested for fibre production than seed production. However, advances agriculture, advances sorted out some method decapitation, top cutting and ratoning for seed production of seed. Sarkar and Sinha 2001, reported higher seed of tossa jute which clipped 45 DAS. In the Gangetic area of W.B. in climatic and other factor has been favourable for jute fibre and seed production separately as stated that Mondal and Chettri, 1998 and Dalai et al. 2001. But production of fibre and seed from same plant rather than been latest concept developed by Mondal et al. (2007) and Mandal et al. (2008). Some limited work has been done on the effect nitrogen and potassium on seed production of jute by different methods. But no work has been done on the effect of integrated nutrient management for production of fibre and seed from the same plant.

3.2. Effect of INM on nutrient uptake $\left(\mathrm{kg} \mathrm{ha}^{-1}\right)$, soil nutrient content and extent of soil nutrient content $\left(\mathrm{kg} \mathrm{ha}^{-1}\right)$ after harvest of jute seed production

There was significant increase in nitrogen uptake by jute crop due to different integrated nutrient management practices in jutefibre (Table 2). The pooled data of the study revealed that $75 \% \mathrm{RDF}+25 \% \mathrm{~N}-\mathrm{FYMrecorded}$ maximum nitrogen uptake (71.34 $\mathrm{kg} \mathrm{N}, 38.71 \mathrm{~kg} \mathrm{P}$ and $109.04 \mathrm{~kg} \mathrm{~K} \mathrm{ha}^{-1}$. In respect to nitrogen uptake, this treatment however was statistically at par with $75 \% \mathrm{RDF}+25 \% \mathrm{~N}-\mathrm{Neem}$ seed powder only. Interestingly, it was significantly higher than rest of the treatments in relation to phosphorus and potassium uptake.

There was significant increase in nitrogen content in the soil after harvest of jute crop for seed production due to different integrated nutrient management practices. Maximum soil nitrogen content (1456.1 ha-1) was obtained in the treatment $75 \% \mathrm{RDF}+25 \% \mathrm{~N}-\mathrm{FYM}$ which was found significantly higher than $100 \%$ RDF from inorganic source only.

Maximum phosphorus in soil (1456.1 kg ha-1) was obtained in the same treatment which recorded significantly more phosphorous uptake than all treatments except $75 \% \mathrm{RDF}+25 \%$ N-Neem seed powder; it was on the other hand, statistically at with $\mathrm{RDF}+25 \% \mathrm{~N}-\mathrm{Neem}$ seed powder and $75 \% \mathrm{RDF}+25 \%$ $\mathrm{N}$-vermicompost while considering the soil potassium content.

As compared to the initial value, the nitrogen status of the soil after harvest of the jute as well as seed production by top cutting were improved when application of $75 \%$ recommended dose of NPK along with $25 \% \mathrm{~N}$ through different sources of organic fertilizers.. Maximum positive value (total N 67.10, available P 14.97 and $28.45 \mathrm{~kg} \mathrm{ha}^{-1}$, respectively) was observed in the treatment receiving $75 \%$ recommended dose of NPK through inorganic sources along with 25\% $\mathrm{N}$ through FYM.

Application of $75 \% \mathrm{RD}$ of $\mathrm{N}, \mathrm{P}$ and $\mathrm{K}$ along with $25 \% \mathrm{~N}$ through different organic sources improved the $\mathrm{K}$ content of the crops which influenced the yield and fibre quality of jute. Bhattacharjee et al. (2000) who reported potassium helped in improvement of seed yield and vigour. This result is also agreement with the findings of Chandra (2006). Such view was supported by Thamang (1974) who observed that the level of potash had a very strong correlation with strength of fibre in olitorious $(\mathrm{r}=0.809)$ and capsularis $(\mathrm{r}=0.818)$ species. This 
Table 1: Effect of integrated nutrient management on growth, yield attributes and yield of jute seed production by top cutting in jute (fibre) (pooled data)

\begin{tabular}{|c|c|c|c|c|c|c|c|c|c|}
\hline Treatments & $\begin{array}{c}\text { Plant } \\
\text { height } \\
\text { at } 60 \\
\text { DAS } \\
(\mathrm{cm})\end{array}$ & $\begin{array}{c}\text { Plant } \\
\text { height } \\
\text { at } 80 \\
\text { DAS } \\
(\mathrm{cm})\end{array}$ & $\begin{array}{c}\text { Plant } \\
\text { height } \\
\text { at har- } \\
\text { vest } \\
(\mathrm{cm})\end{array}$ & $\begin{array}{l}\text { Dry mat- } \\
\text { ter accu- } \\
\text { mulation } \\
\text { unit }^{-1} \text { area } \\
\left(\mathrm{g} \mathrm{m}^{-2}\right)\end{array}$ & $\begin{array}{c}\text { No. of } \\
\text { branches } \\
\text { plant }^{-1}\end{array}$ & $\begin{array}{l}\text { No. of } \\
\text { pods } \\
\text { plant }^{-1}\end{array}$ & $\begin{array}{l}\text { No. of } \\
\text { seeds } \\
\text { pod }^{-1}\end{array}$ & $\begin{array}{c}\text { Test } \\
\text { weight } \\
(\mathrm{g})\end{array}$ & $\begin{array}{c}\text { Seed } \\
\text { yield } \\
\left(\mathrm{t} \mathrm{ha}^{-1}\right)\end{array}$ \\
\hline $100 \% \mathrm{RDF}$ & 43.1 & 61.3 & 71.2 & 950.4 & 5.0 & 42.5 & 180.9 & 2.00 & 0.34 \\
\hline $75 \% \mathrm{RDF}+25 \% \mathrm{~N}-$ Karanja cake & 59.2 & 77.4 & 96.5 & 1289.5 & 6.7 & 54.2 & 186.3 & 2.02 & 0.43 \\
\hline $75 \% \mathrm{RDF}+25 \% \mathrm{~N}-\mathrm{Neem}$ seed powder & 66.4 & 84.9 & 114.5 & 1407.1 & 7.4 & 64.0 & 194.1 & 2.03 & 0.49 \\
\hline $75 \% \mathrm{RDF}+25 \% \mathrm{~N}-\mathrm{OM}$ rich with humas & 51.1 & 71.6 & 86.6 & 1235.4 & 5.6 & 50.3 & 183.8 & 2.00 & 0.39 \\
\hline $\begin{array}{l}75 \% \mathrm{RDF}+25 \% \mathrm{~N}-\text { Pelleted form of } \\
\text { organic manure }\end{array}$ & 61.3 & 79.6 & 99.4 & 1315.4 & 6.9 & 56.5 & 187.6 & 2.01 & 0.45 \\
\hline $75 \% \mathrm{RDF}+25 \% \mathrm{~N}$-vermicompost & 65.3 & 84.5 & 112.5 & 1375.2 & 7.4 & 62.7 & 193.1 & 2.03 & 0.48 \\
\hline $75 \% \mathrm{RDF}+25 \%$ N-Jatropha cake & 53.2 & 74.7 & 89.6 & 1254.4 & 5.7 & 53.0 & 184.4 & 2.01 & 0.40 \\
\hline $75 \% \mathrm{RDF}+25 \% \mathrm{~N}-\mathrm{FYM}$ & 67.3 & 85.7 & 117.5 & 1504.0 & 7.5 & 69.8 & 199.1 & 2.05 & 0.52 \\
\hline $75 \% \mathrm{RDF}+$ Azospirillum & 48.3 & 68.6 & 82.6 & 1123.8 & 5.3 & 49.3 & 183.4 & 2.00 & 0.37 \\
\hline $\mathrm{SEm} \pm$ & 1.3 & 1.7 & 2.4 & 43.7 & 0.1 & 2.8 & 2.2 & 0.01 & 0.03 \\
\hline $\mathrm{CD}(p=0.05)$ & 3.9 & 5.1 & 7.1 & 130.5 & 0.5 & 8.3 & 6.5 & NS & 0.08 \\
\hline
\end{tabular}

Table 2: Effect of integrated nutrient management on nutrient uptake $\left(\mathrm{kg} \mathrm{ha}^{-1}\right)$, soil nutrient content and extent of increase $(+)$ or decrease (-) of soil nutrient content $\left(\mathrm{kg} \mathrm{ha}^{-1}\right)$ after harvest of jute seed production by top cutting in jute (fibre) (pooled data)

\begin{tabular}{|c|c|c|c|c|c|c|c|c|c|}
\hline Treatments & $\begin{array}{l}\text { Nitro- } \\
\text { gen } \\
\text { uptake } \\
(\mathrm{kg} \\
\left.\mathrm{ha}^{-1}\right) \\
\end{array}$ & $\begin{array}{l}\text { Phos- } \\
\text { phorus } \\
\text { uptake } \\
(\mathrm{kg} \\
\left.\mathrm{ha}^{-1}\right) \\
\end{array}$ & $\begin{array}{l}\text { Potas- } \\
\text { sium } \\
\text { uptake } \\
(\mathrm{kg} \\
\left.\mathrm{ha}^{-1}\right) \\
\end{array}$ & $\begin{array}{c}\text { Soil ni- } \\
\text { trogen } \\
\text { content } \\
(\mathrm{kg} \\
\left.\mathrm{ha}^{-1}\right) \\
\end{array}$ & $\begin{array}{c}\text { Soil } \\
\text { phos- } \\
\text { phorus } \\
\text { content } \\
\left(\mathrm{kg} \mathrm{ha}^{-1}\right) \\
\end{array}$ & $\begin{array}{c}\text { Soil po- } \\
\text { tassium } \\
\text { content } \\
(\mathrm{kg} \\
\left.\mathrm{ha}^{-1}\right) \\
\end{array}$ & $\begin{array}{l}\text { Total } \\
\mathrm{N}(\mathrm{kg} \\
\left.\mathrm{ha}^{-1}\right)\end{array}$ & $\begin{array}{c}\text { Avail- } \\
\text { able P } \\
(\mathrm{kg} \\
\left.\mathrm{ha}^{-1}\right)\end{array}$ & $\begin{array}{l}\text { Avail- } \\
\text { able } \\
\mathrm{K}(\mathrm{kg} \\
\left.\mathrm{ha}^{-1}\right)\end{array}$ \\
\hline $100 \% \mathrm{RDF}$ & 34.79 & 21.99 & 58.51 & 1382.6 & 16.3 & 173.5 & -6.36 & -1.99 & -6.24 \\
\hline $75 \% \mathrm{RDF}+25 \% \mathrm{~N}-$ Karanja cake & 56.71 & 30.19 & 81.01 & 1422.4 & 28.3 & 194.8 & 33.35 & 10.06 & 15.08 \\
\hline $75 \% \mathrm{RDF}+25 \%$ N-Neem seed powder & 67.97 & 34.76 & 94.79 & 1450.0 & 35.0 & 206.9 & 61.03 & 15.21 & 27.15 \\
\hline $75 \% \mathrm{RDF}+25 \% \mathrm{~N}-\mathrm{OM}$ rich with humas & 47.91 & 28.30 & 74.46 & 1409.0 & 25.3 & 189.2 & 20.01 & 7.04 & 9.52 \\
\hline $\begin{array}{l}75 \% \mathrm{RDF}+25 \% \mathrm{~N}-\text { Pelleted form of } \\
\text { organic manure }\end{array}$ & 58.12 & 31.18 & 83.31 & 1435.7 & 30.5 & 197.4 & 46.70 & 12.25 & 17.77 \\
\hline $75 \% \mathrm{RDF}+25 \% \mathrm{~N}$-vermicompost & 64.58 & 33.50 & 94.00 & 1443.5 & 33.2 & 208.3 & 54.53 & 14.97 & 28.45 \\
\hline $75 \% \mathrm{RDF}+25 \%$ N-Jatropha cake & 51.93 & 29.34 & 77.57 & 1430.2 & 26.4 & 195.7 & 41.19 & 8.16 & 12.46 \\
\hline $75 \% \mathrm{RDF}+25 \% \mathrm{~N}-\mathrm{FYM}$ & 71.34 & 38.71 & 109.04 & 1456.1 & 35.8 & 210.4 & 67.10 & 17.53 & 30.91 \\
\hline $75 \% \mathrm{RDF}+$ Azospirillum & 42.96 & 25.10 & 67.21 & 1399.7 & 23.4 & 183.6 & 10.71 & 5.13 & 3.88 \\
\hline $\mathrm{SEm} \pm$ & 0.66 & 0.50 & 0.40 & 19.8 & 0.5 & 3.0 & & & \\
\hline $\mathrm{CD}(p=0.05)$ & 1.97 & 1.48 & 1.20 & 59.3 & 1.4 & 9.0 & & & \\
\hline
\end{tabular}

result is agreement with the findings of Mondalet al. (1993).

\section{Conclusion}

Among the integrated management treatments, $75 \% \mathrm{RDF}+25 \%$ N-FYM proved best not only in influencing highest growth and yield but also in balancing soil nutrients.

\section{References}

Bhattacharjee A.K., Mitra, B.N. and Mitra, P.C. 2000 production and quality of Corchorus olitorius seed as influenced by nutrient management. Seed Science. Technology 28, 141-154.

Chandra, P., 2006. Studies on production potential of olitorius 
jute as dual purpose (fibre and seed) through integrated nutrient management. Ph.D. Thesis, Bidhan Chandra KrishiViswavidyalaya, Mohanpur, Nadia, West Bengal, India.

Dalai, G.M., Mondal, S.S., Maity, G.C., 2001. Production potential of jute seed as influenced by potassium sulphur and decapitation for sustainable agriculture. National Seminar on Frontiers of Crop Management, 84-86.

Mandal, P., Mondal, S.S., Sarkar, S., 2008. Dual production of fibre as well as seed from the same jute plant by top cutting method.International symposium on jute and allied fibre production, utilization and Marketing, January 9-12, CRIJAF, Barrackpore, 69.

Mondal S.S., Sarkar, S., Das, T.K., 2003.Seed production of jute (Corchorus olitorius) as influenced by potassium, sulphur and decapitation. Journal of Potassium Research 19, 103-106.

Mondal, S.S., Chettri, M., 1998. Integrated nutrient management for sustaining productivity and fertility under rice (Oryza sativa)-based cropping system. Indian Journal of
Agricultural Sciences 68(7), 337-340.

Mondal, S.S., Dasmahapatra, A.N., Chatterjee, B.N., Maity, P.K., 1993. Effect of potassium on the oil content of oil seed crops and quality of jute crop. Abstract of International Symposium on a decade of Potassium Research.Organized by Potash Research Institute, India, 18-20 Nov., 1993, New Delhi, 95.

Mondal, S.S., Sarkar, S., Mandal, P., Saha, M., 2007. Effect of potassium and sulfur on seed production of olitorius jute raised from top cutting. Environment and Ecology 25(3), 484-486.

Sarkar, A.K., Sinha, A.C., 2004. Seed production of tossa jute (Corchorus olitorius L.) as influenced by time of sowing and clipping apical bed under rainfed condition in Terai Region of West Bengal. Journal of Interacademicia 8(1), 21-26.

Thamang, D.B., 1974. Effect of potash and soil compaction on growth, yield and quality of jute. M. Sc. Thesis, Bidhan Chandra KrishiViswavidyalaya, Mohanpur, Nadia, West Bangal, India. 